\title{
Organogels in Drug Delivery: A Special Emphasis on Pluronic Lecithin Organogels
}

\author{
Hashem Alsaab, Sindhu Prabha Bonam, Dherya Bahl, Pallabita Chowdhury, Kenneth Alexander, Sai HS. Boddu \\ Department of Pharmacy Practice, The University of Toledo, Health Science Campus, 3000 Arlington Ave. Toledo, OH.
}

Received, April 18, 2016; Revised, May 10, 2016; Accepted, July 8, 2016; Published, July 11, 2016.

\begin{abstract}
Organogels have emerged as an alternative carrier for small and macromolecules via transdermal, oral, rectal and ophthalmic routes. Pluronic lecithin organogels (PLO gels) are lecithin-based organogels widely used in compounding pharmacies as a vehicle for enhancing the transdermal permeability of many therapeutic drugs. However, the scientific and systematic evidence in support of how well PLO gels help in transdermal delivery is scanty. Recently, some clinical studies have reported nearly complete lack of bioavailability of certain topically administered drugs from PLO gels. The present review aims at summarizing gels and organogels, with a focus on the use of PLO gels in transdermal drug delivery. A special emphasis is placed on controversies looming over the use of PLO gels as a delivery platform for drugs via transdermal route.

This article is open to POST-PUBLICATION REVIEW. Registered readers (see "For Readers") may comment by clicking on ABSTRACT on the issue's contents page.
\end{abstract}

\section{Gels in drug delivery}

According to the United States Pharmacopeia (USP), a gel is a formulation in a water-soluble base and may be regarded as a greaseless ointment. Gels are defined as semi-solid formulations comprising of an external solvent phase, either polar or nonpolar in nature, that is immobilized within the spaces of a three dimensional network $(1,2)$. This is often referred to as the gelator system. The gelator prevents the flow of solvent phase predominantly by causing a rise in the surface tension $(3,4)$. Gels may be classified as physical or chemical gels depending on the strength of bonds within the gelator system. In physical gels, the type of bonding may occur as van der Waal's forces or hydrogen bonding; however, chemical gels are held together by covalent bonds. Gels are basically classified into two types, depending upon the nature of the liquid component, as organogels and hydrogels (Fig. 1).

Hydrogels are three-dimensional polymeric networks that are hydrophilic in nature and capable of imbibing large quantities of water or biological fluids (4). Insoluble homopolymers or copolymers form networks, which are insoluble owing to the presence of cross-links. Physical cross-links include molecular entanglements or crystallites that contribute to the network formation and physical integrity, while the chemical cross-links can be seen as tie-points and junctions $(3,5-8)$. These crosslinks are formed via physical entanglements, hydrogen binding, van der Waals interactions or covalent bonds. The "tie-point" or "junction" or "cross-link" specify connection points such as carbon atoms contained in a small chemical bridge (e.g., an cetal bridge in poly(vinyl alcohol)) or associations of macromolecular chains due to van der Waals forces (e.g., glycoprotein network structure present in mucus) or an aggregate formed by hydrogen bonds (e.g., aged microgels in polymer solutions) (9). The hydrogels swell in the presence of an aqueous environment because of the thermodynamic compatibility they exhibit with water (10-14). Hydrogels have a wide range of applications in the pharmaceutical industry (15-17). They show a resemblance to natural living tissues in terms of their water content and soft texture (15), while the high water content contributes to their biocompatibility. As a result, hydrogels are widely used as contact lenses membranes for biosensors, linings for artificial hearts, materials for artificial skin and drug delivery devices (15-19). Organogels are thermodynamically stable, viscoelastic bi-phasic systems comprising of a gelator and a organic phase, with or without the presence of water molecules within the network formed by the gelator

\footnotetext{
Corresponding Author: Sai HS. Boddu, Department of Pharmacy Practice, The University of Toledo, Health Science Campus, 3000 Arlington Ave. Toledo, OH 43614.

sboddu@utnet.utoledo.edu
} 
system. They have a lower degree of hydration when compared to hydrogels. They gained importance in drug delivery over the past few years owing to their non-irritating nature and biocompatibility. The organogel systems exhibit morphological and rheological properties similar to solids, even though they are composed of large amounts of liquid (20). The thermodynamic and kinetic stability of these systems can be attributed to the opposing forces that are operating and are associated with the organogelator's partial solubility in the continuous phase. The physicochemical properties of gel components and their resulting interactions govern the formation of the gelling matrix. Organogels can be classified based on the properties of gelators, solvents and intermolecular interactions that can occur in gels. Table 1 lists the classification of organogelators used widely in the preparation of organogels. Administration of drugs requires variations in the formula of organogels used, depending upon the route of drug administration (21). The advantages of organogels are reported in literature are manifold: (a) ease of preparation and administration, (b) fewer number of ingredients, which minimizes the overall production cost, (c) they act as good permeation enhancers, (d) enhanced patient compliance due to the non-toxic and non-irritating nature of the gels, (e) they act as a carrier system for the delivery of a wide variety of hydrophilic and lipophilic drugs, and (f) drug release for sustained delivery can be achieved by modifying the structure of the organogelator and the type of organic phase used (22). Organogel networks are formed via two mechanisms: polymerization and low molecular weight (LMW) gelators (Fig. 1). In the polymerization mechanism, a precursor solution of monomers with various reactive sites grows into a covalently-linked network of polymeric chains. At the gel point, the polymeric network solution exhibits gel-like physical properties (23). Organogels of LMW gelators (MW $3000 \mathrm{Da}$ ) form gels via selfassembly due to secondary forces such as van der Waals or hydrogen bonding (3). These forces result in the formation of non-covalently bonded cluster networks that retain the organic solvent and exhibit gel-like physical properties (24).

\section{Classification of gels}

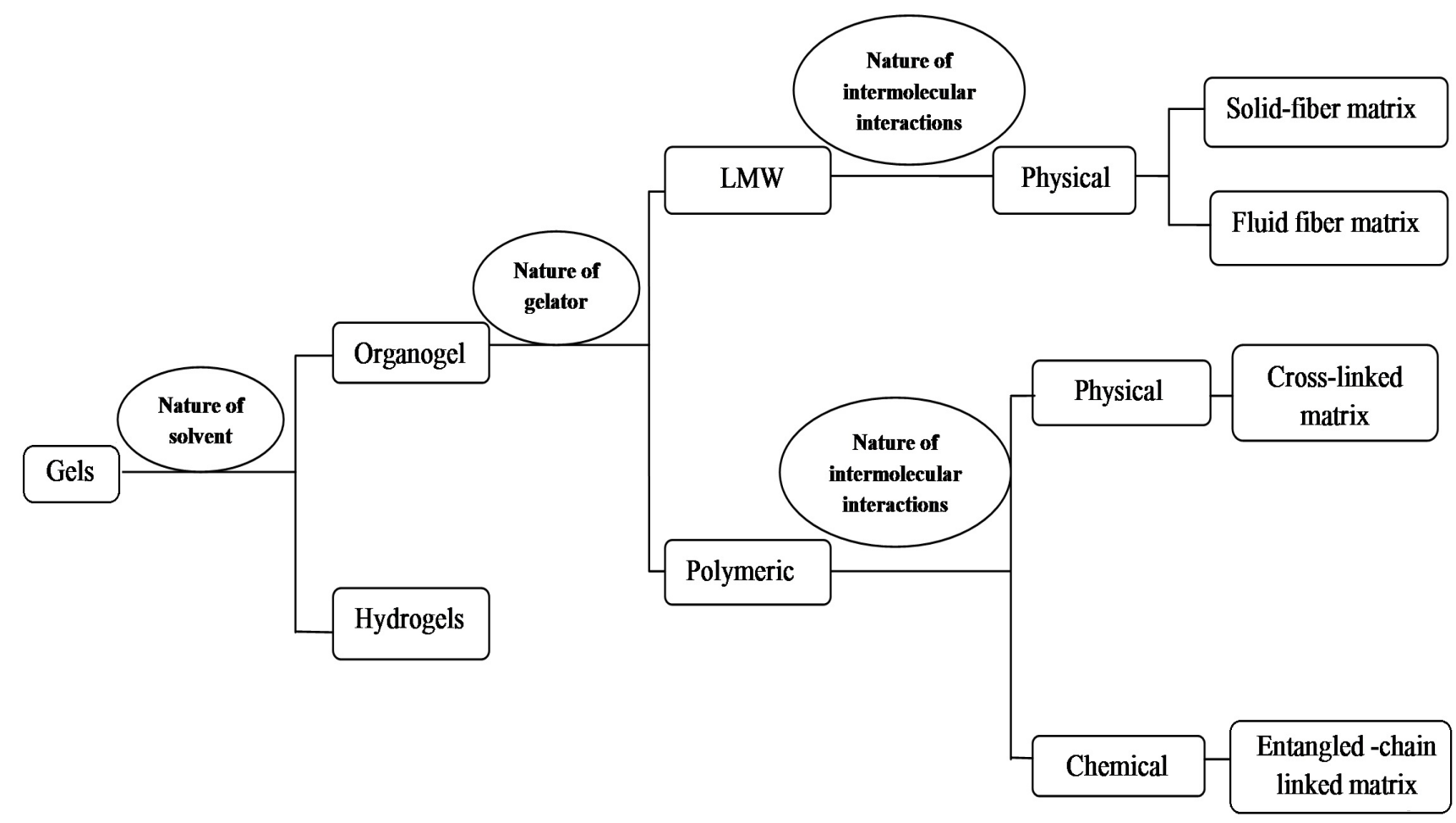

Figure 1: Classification of organogels. Modified from (21). 
Table 1. Classification of organogelators

\begin{tabular}{|c|c|c|c|}
\hline $\begin{array}{l}\text { Types of } \\
\text { Organogelators }\end{array}$ & Examples & Properties of organogel & Potential applications \\
\hline $\begin{array}{l}\text { Arylcyclohexanol } \\
\text { derivatives }\end{array}$ & $\begin{array}{l}\text { 4-tertbutyl-1-aryl } \\
\text { cyclohecanols derivatives }\end{array}$ & $\begin{array}{l}\text { Solid at room temperature, low } \\
\text { solubility in apolar solvent }\end{array}$ & $\begin{array}{l}\text { Topical formulations } \\
\text { (97) }\end{array}$ \\
\hline $\begin{array}{l}\text { Polymeric } \\
\text { organogelators }\end{array}$ & $\begin{array}{l}\text { Polycarbonate, polyesters, } \\
\text { poly(ethylene glycol) and } \\
\text { poly(alkylene) }\end{array}$ & $\begin{array}{l}\text { Low sol-gel processing } \\
\text { temperature, good gel strength }\end{array}$ & $\begin{array}{l}\text { Used in the preparation } \\
\text { of organogels and } \\
\text { sustained release } \\
\text { formulations for rectal } \\
\text { administration (98) }\end{array}$ \\
\hline Gemini gelators & $\begin{array}{l}\text { N-lauroyl-L-lysine ethyl } \\
\text { ester) solvents }\end{array}$ & $\begin{array}{l}\text { High ability of immobilizing } \\
\text { apolar }\end{array}$ & $\begin{array}{l}\text { Topical formulations } \\
\text { (97) }\end{array}$ \\
\hline Synthetic tripeptide & $\begin{array}{l}\text { Boc-Ala(1)-Aib(2)-B-Ala(3)- } \\
\text { OMe }\end{array}$ & $\begin{array}{l}\text { Capable of self-assembling, } \\
\text { thermoreversible; transparent }\end{array}$ & $\begin{array}{l}\text { Drug delivery, } \\
\text { optoelectronics, sensors } \\
(99)\end{array}$ \\
\hline $\begin{array}{l}\text { Low molecular weight } \\
\text { gelators }\end{array}$ & Fatty acids and n-alkanes & $\begin{array}{l}\text { High ability to immobilize } \\
\text { apolar solvents at small } \\
\text { concentrations }(<2 \%)\end{array}$ & Food industry (100) \\
\hline
\end{tabular}

\section{LMW organogelators}

The organogelation phenomenon exhibited by LMW organogelators has received increasing attention in the last two decades. Depending on the physical intermolecular interactions, LMW organogelators produce either solid-fiber matrix or fluid-fiber matrix gels. Solid-fiber matrix is produced by a fall in the temperature below the solubility limit of the gelator (25). This is followed by a quick precipitation of gelator molecules in the organic medium to some extent, which leads to the formation of aggregates by co-operative intermolecular interactions (26). Solid-fiber matrix gels are prepared by the dissolution of a gelator in a hot solvent in a concentration ranging between 0.1$15 \%$ (27). As the temperature falls, the affinity between the gelator and the solvent molecules decreases. As this occurs, the gelator assembles itself into solid aggregates that are bound by intermolecular interactions. However, the system is stabilized by the remaining solvent-aggregate affinity. The formation of aggregates occurs in two ways:

1) Unidimensional growth of fibers in high specific (length-to-width) ratios, which measures tens of nanometers and micrometers in length. Most aggregates fall under this category (e.g., L-alanine fatty acid derivatives) (28).
2) Two-dimensional growth of fibers (e.g., hexatriacontane, which forms microplatelet arrangements) (28).

On the other hand, the fluid-fiber matrices are formed by the realignment of surfactant molecules in single or bi-layered cylindrical molecules, where polar molecules are incorporated into surfactants present in organic solutions. The cylindrical aggregates thus formed immobilize the solvent (26). The solid and fluid-fiber matrices vary from one another with respect to the kinetic stability of networks that form the gel system. Strong gels are formed by permanent, and mostly crystalline, networks (4), while weak gels are formed from transient networks $(29,30)$. Physical properties of organogels are determined by the nature of the networks they form. Solid-matrix fibers are known for their robustness, owing to their aggregation and alignment to form bundles because of their rigidity (26). This has been demonstrated by rheological studies $(4,10)$. However, this aggregation does not take place in fluid-fiber matrix. Molecular and supramolecular chirality greatly influences the formation and stability of solid fibers, while its occurrence in fluid- fiber matrix is rare $(25,26)$. Fluid-fiber matrices are thermoreversible gels that may be transparent or opaque. They are also known as worm-like or polymer-like networks because of their aggregate fluidity and transient junctions. Organogels of lecithin and sorbitan monostearate have a wide range of pharmaceutical applications. 
Lecithin organogels are gaining importance, owing to their biocompatibility, their amphiphilic nature, which allows the permeation of lipophilic and hydrophilic drugs, and their permeation-enhancing properties. Lecithin has the ability to form different shapes, owing to its amphiphilic nature (31). Reverse micelles with hydrophilic groups at the core of micelles and hydrophobic groups at the surface are formed when a small amount of organic solvent is added to lecithin. Cylindrical reverse micelles start growing, upon the addition of polar solvents, until they intertwine to form a gelling network. In spite of being known as "weak" organogels, lecithin organogels have higher viscosities than that of gelatin. The high viscosity of these systems was found to be a result of the growth and overlapping of the reverse tubular micelles (32$34)$.

\section{Mechanism of organogelation}

Lecithin molecules undergo gelation upon the addition of a polar solvent. Lecithin tends to selfassemble into reverse spherical micelles at a concentration of $\sim 0.01 \mathrm{mM}$ in the presence of a nonpolar medium (35). However, the addition of small and critical quantities of a polar solvent induces an aggressive uniaxial growth of spherical micelles into tubular or cylindrical micellar aggregates (Fig. 2) (36). The binding of the polar molecules in stoichiometric ratios to the hydrophilic head of lecithin molecules results in the formation of a linear framework, where two adjacent lecithin molecules are linked by a polar molecule (36-38). This linear framework is a result of hydrogen bonds formed by polar molecules and the phosphate group of lecithin molecules. These bonds are also responsible for the one dimensional growth of reverse micelles of lecithin. Long tubular micelles of 2.0-2.5 $\mathrm{nm}$ radius and hundreds to thousands of nanometers will be formed upon further addition of polar solvent $(39,40)$. Once these micelles attain a critical length, they start to overlap, followed by the intertwining, which results in the formation of a three-dimensional network $(29,41-46)$. This offers the system an enhanced viscosity and viscoelastic property, which results in the formation of a jellylike structure. Micellar aggregates are further stabilized by the rigidity of the phospholipid in the phosphate group region and glycerol residue. Pluronic lecithin organogels (PLO gels) are prepared by the addition of synthetic polymers (e.g., pluronics) into lecithin organogels.

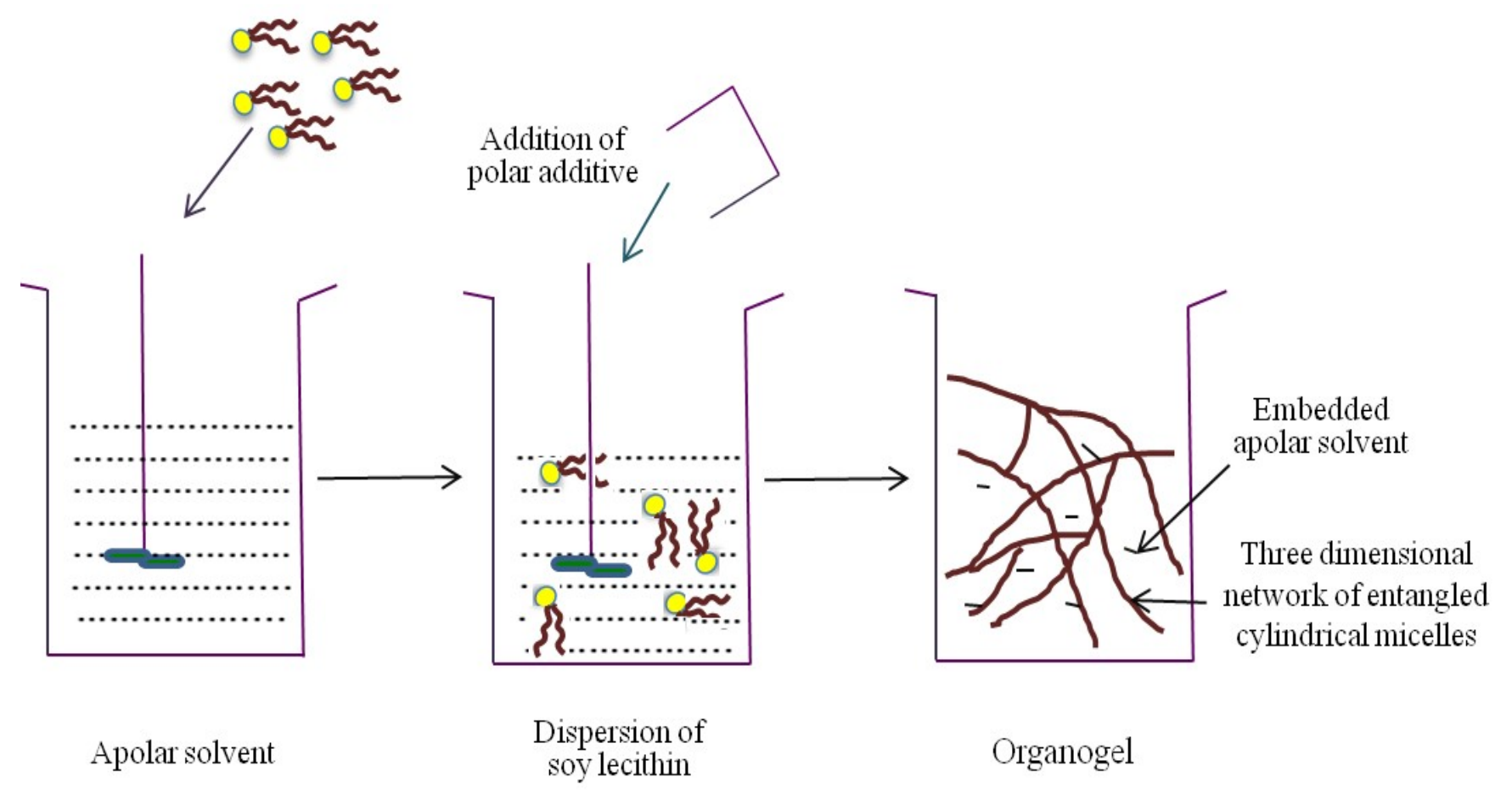

Figure 2: Different steps in the formation of a lecithin organogel. Modified from Kumar et al. (36) 


\section{Pluronic Lecithin Organogels (PLO gels)}

PLO gels have gained importance as transdermal drug delivery systems. PLO gel, introduced in the 1990 s by Jones and Kloesel (47), is a biphasic system consisting of an oil phase (lecithin dissolved in isopropyl myristate or isopropyl palmitate in a $1: 1$ ratio) and a water phase containing $20-30 \%$ poloxamer (48). It is a thermodynamically stable, viscoelastic system, which is non-irritating, odorless and biodegradable. Pluronic F127, or poloxamer, is a copolymer of polyoxyethylene and polyoxypropylene that forms a thermoreversible gel in concentrations between $15-30 \% \mathrm{w} / \mathrm{v}$. Poloxamer exists in a liquid state at refrigerated conditions $\left(4^{\circ} \mathrm{C}\right)$ and forms a gel at room or body temperature. Water plays the role of a structure-forming agent and stabilizes the process of gel formation as it solubilizes the pluronic and other hydrophilic drugs. Lecithin, a lipid composed of choline and inositol, is found as a major component of cell membranes. Lecithin is a surfactant with emulsification and lubricant properties. Isopropyl palmitate acts as an emollient, moisturizer and penetration enhancer (49). Our group has recently suggested the use of ricinoleic acid as an alternative to isopropyl palmitate, especially for delivering nonsteroidal anti-inflammatory drugs (50). Better thixotropic properties were observed for PLO gels prepared using ricinoleic acid compared to traditional PLO gels prepared using isopropyl palmitate (48). Sorbic acid or potassium sorbate may be used as the preservative to enhance the shelf-life of the gel. PLO gels have generated significant interest in the United States as transdermal and topical drug delivery vehicles in compounding pharmacies. A PLO gel system facilitates the delivery of some hydrophilic and lipophilic drugs, owing to the presence of both oil and aqueous phases within the gel system. Over the last two decades, PLO gels have been studied for the topical delivery of hormones, antiemetics, opioids, antipsychotic drugs, calcium channel blockers and local anesthetics (51). The drawbacks of a PLO gel system include separation in cold temperatures or low $\mathrm{pH}$ ranges, rendering it unusable and aesthetically unpleasant. Despite the drawbacks, currently there are about 85 PLO gel formulations listed on CompoundingToday.com, a product of the International Journal of Pharmaceutical Compounding (IJPC). Recently, marketed PLO gel kits such as Transderma $^{\circledR}$, Phlojel $^{\circledR}$ and PLO transdermal cream have become increasingly popular. The marketed kits are loaded with suitable drugs, depending on patient requirements (52). Imprimis Pharmaceuticals, Inc., in collaboration with Professional Compounding Centers of America (PCCA), owns a patented topical delivery technology called Accudel, a PLO gel formulation, and Impracor, a 10\% ketoprofen based Accudel delivery technology. In July 2013, the company wanted to initiate a randomized, double-blind, placebo-controlled, at 26 sites comparing Impracor vs. placebo (Vehicle) cream, 1g t.i.d. x 7 days. However, the study was delayed due to manufacturing issues and there is no update since then (Source: http://www.prnewswire.com/newsreleases/imprimis-pharmaceuticals-inc-commentson-delay-in-phase-iii-impracor-program-

219242191.html).

\section{General characteristics of Pluronic Lecithin Organogels (53, 54):} Viscoelasticity: PLO gels have both viscous and elastic properties. A PLO gel behaves like a solid with elastic properties at lower shear rates. The organogel structure will disrupt as the shear stress is increased, resulting in flowability. Non-birefringence: PLO gels do not allow polarized light to pass through its matrix; therefore, they appear dark in this light. Thermo-reversibility: At poloxamer concentration ranging between $20-30 \%$, PLO gel lose their fiber structure and start to flow when the temperature of the organogel goes below the critical limit temperature of $20-25^{\circ} \mathrm{C}$ (55). However, with increase in temperature, PLO gels revert back to a more stable configuration. Thermostability: PLO gels are thermostable due to the ability of the gelator system to undergo selfassembly, under appropriate conditions. Optical clarity: Lecithin organogels are transparent, while PLO gels are yellow-colored and opaque in nature.

\section{Poloxamer as a gelling agent}

Poloxamers are polymers of ethylene oxide and propylene oxide, arranged in a triblock fashion (Fig. 3 ). The lipophilicity, hydrophilicity and size of the poloxamers can be modified by changing the "a" and " $b$ " values (Table 2). They exhibit reversible thermodynamic properties, which plays a crucial rule in designing a formulation. Commercially, they are available under the names Pluronic ${ }^{\circledR}$, Synpersonic $^{\circledR} \quad$ or Tetronic $^{\circledR} \quad$ (56). Different 
poloxamer grades, which have different physical and chemical properties, are marketed. Poloxamer 407 is the most commonly used pluronic in the pharmaceutical industry. It is a tri-block copolymer that exhibits thermoreversible behavior in aqueous solutions; it consists of $\sim 70 \%$ polyoxyethylene units and $\sim 30 \%$ polyoxypropylene blocks. This polymer is characterized by low toxicity, excellent compatibility with other chemicals, and a high solubilizing capacity for different drugs (57). They exhibit a thermoreversible property above a certain temperature, known as the sol-gel transition temperature. They act as solids above the sol-gel transition temperature and as liquids below that same temperature. The gelation process takes place in two steps (Fig. 4). In the first step, co-polymers aggregate, resulting in the formation spherical micelles. Hydrated swollen polyethylene oxide
(EO) chains form the outer lining of micelles, while the dehydrated polypropylene oxide (PO) blocks occupy the inner core portion (58). The first step takes place as temperature increases and reaches the critical micellar temperature. A further increase in the temperature results in the alignment of micelles in a uniform fashion, which results in the formation of gels $(55,58)$. Poloxamers varying in concentration between $20-30 \%$, which are clear liquids at $4-5^{\circ} \mathrm{C}$ and gels at room temperature, are generally used in pharmaceutical formulations. These solutions are generally prepared by the cold method (using cold water), in which a layer of water molecules surrounds the poloxamer molecule. This leads to the separation of hydrophobic portions as a result of hydrogen bonding between the water and hydrophilic chains (55).

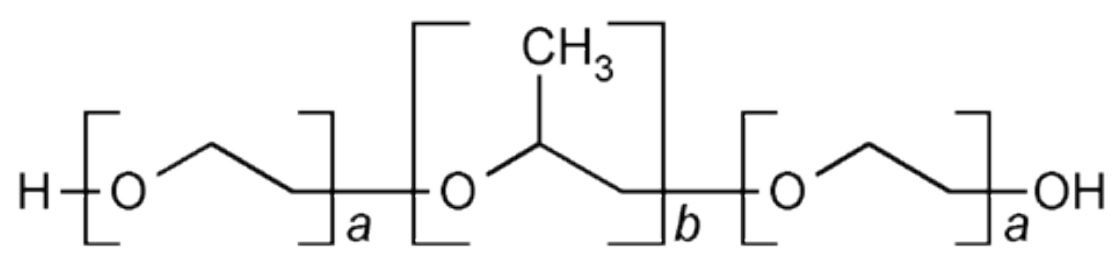

Figure 3: General structure of Poloxamers

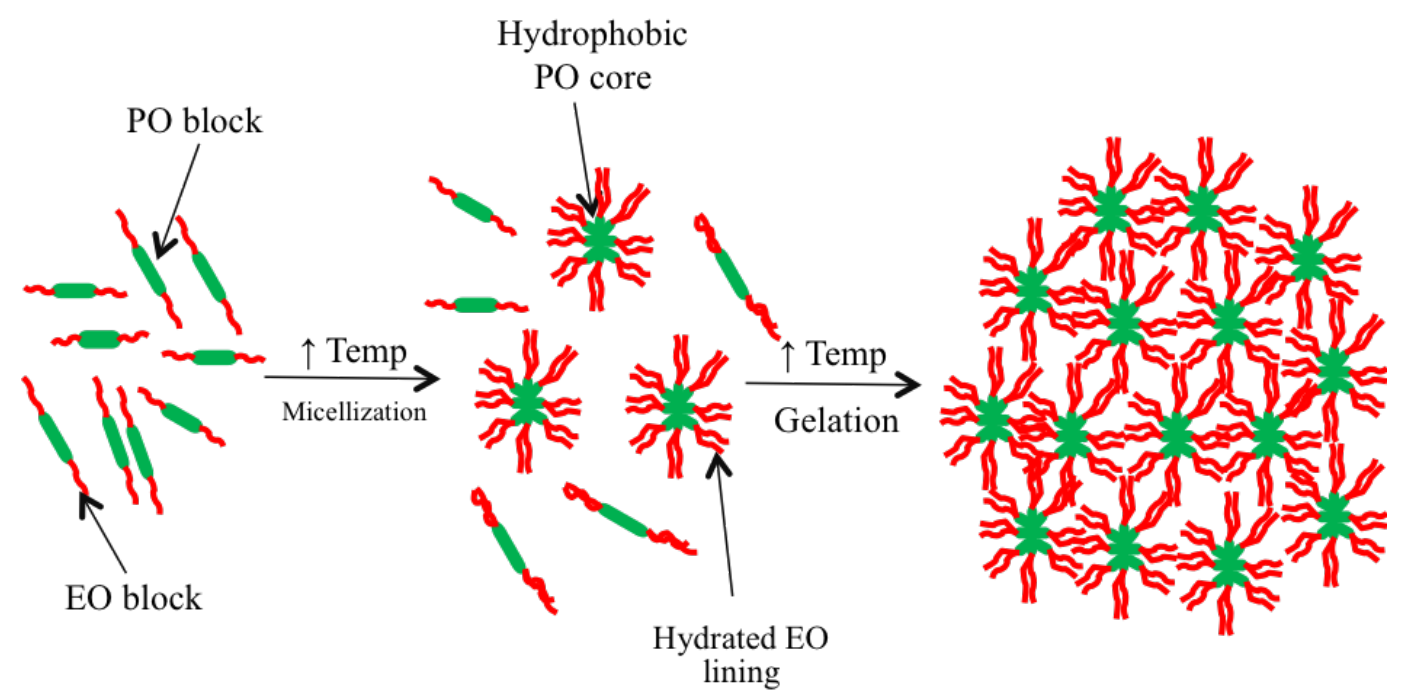

Figure 4: Mechanism of gelation of poloxamer in presence of water. Modified from Dumortier et al. (114). 
Table 2: Different marketed brands of poloxamers with their pluronic name [50].

\begin{tabular}{lllll}
\hline Pluronic ${ }^{\circledR}$ & Poloxamer & a & B & Molecular weight (gram/mole) \\
\hline L 44 NF & 124 & 12 & 20 & $2090-2360$ \\
F 68 NF & 188 & 80 & 27 & $7680-9510$ \\
F87 NF & 237 & 64 & 37 & $6840-8830$ \\
F 108 NF & 338 & 141 & 44 & $12700-17400$ \\
F127 NF & 407 & 101 & 56 & $9840-14600$ \\
\hline
\end{tabular}

Structure of poloxamer: $\mathrm{HO}\left(\mathrm{C}_{2} \mathrm{H}_{4} \mathrm{O}\right)_{a}\left(\mathrm{C}_{3} \mathrm{H}_{6} \mathrm{O}\right)_{\mathrm{B}}\left(\mathrm{C}_{2} \mathrm{H}_{4} \mathrm{O}\right)_{a} \mathrm{H}$

\section{Method of preparation of PLO gel}

The oil phase is prepared by mixing lecithin and isopropyl palmitate or isopropyl myristate (acts as a non-oleaginous emollient with very good spreading ability and is also used for solubilizing the lecithin) and allowing the mixture to stand overnight to ensure complete dissolution. The aqueous phase is prepared by adding poloxamer to ice-cold water, placing the mixture in a refrigerator and agitating periodically to ensure complete dissolution. Sorbic acid at $0.2 \%(\mathrm{w} / \mathrm{w})$ or potassium sorbate is often added to the two phases as preservatives. The oil phase is then mixed with the aqueous phase (chilled before mixing) using a high-shear mixing method. When subjected to proper shearing forces (generally accomplished by rapidly passing the mixture between a small caliber catheter or two syringes, micelles containing the drug are theoretically formed $(59,60)$. Ricinoleic acid has been used as an alternative to isopropyl palmitate in compounding stable PLO gels for drugs used in pain and inflammation management. The $\mathrm{pH}$ of PLO gel prepared with ricinoleic acid was comparable with the isopropyl palmitate PLO gel. Moreover, ricinoleic acid PLO gel exhibited better recovery properties compared to isopropyl palmitate PLO gel (Fig. 5) (60, 61). The ricinoleic acid PLO gel curve appears as shear-thinning at higher RPMs, but showed thixotropy at low RPMs. It is important that the aqueous phase is cold before mixing because an aqueous solution of Pluronic F127 is in the liquid state at a low temperature and gels at a higher temperature. The synergistic action of phospholipids and polymeric surfactant molecules in their respective hydrated states contributes to the gelling and structural network. Generally, lipophilic drugs are solubilized in the organic phase (mixture of apolar solvent and lecithin), while hydrophilic drugs can be solubilized in the polar phase. The addition of the polar phase to the organic phase, under continuous stirring, results in the formation of an organogel.

\section{PLO gels for transdermal drug delivery}

The coexistence of organic and aqueous phases by means of a structurally well-defined micellar network of phospholipids, a large interfacial area, and the possibility to entrap solutes within the gel matrix, along with long-term stability, makes PLO gels useful for a variety of applications. The organized microstructural matrix, amphiphilicity, supersolubilising capacity and interaction of biolipids with skin tissues are some of the major promoting factors for enhanced transport of drug molecules into or across the skin. PLO gels contain several micellar structures. Micelles are believed to slightly disorganize the stratum corneum with minimal direct detrimental effects on the skin (based on light microscopy), although contact hypersensitivity or allergy to the lecithin component may occur (62). PLO gels have garnered huge attention due to their ability deliver drugs both locally and systemically after topical application (63). The ideal properties of drugs that favor transdermal delivery are listed in Table 3. Many medications such as chlorpromazine, lorazepam, morphine, and haloperidol have been formulated into topical gel formulations, either alone or in combination with products such as $\mathrm{ABH}$ (lorazepam, diphenhydramine, and haloperidol) gel (64-66). Transdermal PLO gels are applied with the goal of cutaneous absorption to achieve systemic activity (54). Drugs incorporated in PLO gels for either local or systemic effects are summarized in Table 4. 


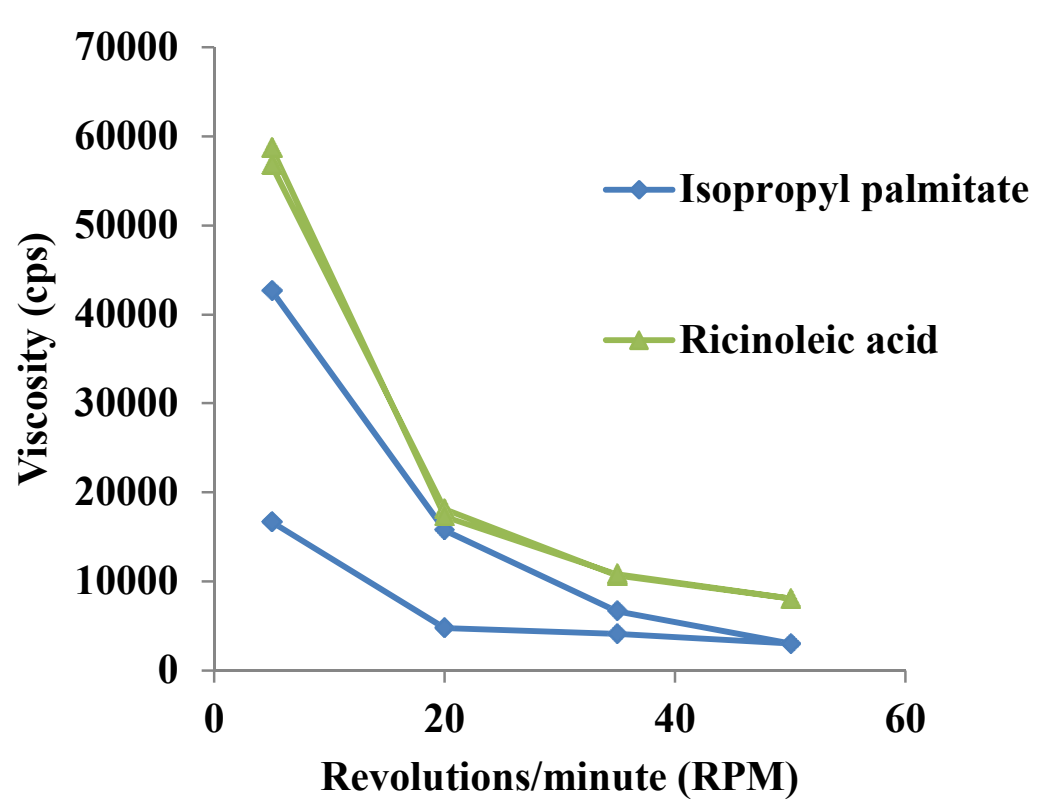

Figure 5: Viscosity data of PLO gels containing isopropyl palmitate and ricinoleic acid. Reproduced from (61).

Table 3: Ideal properties of drug candidate for transdermal drug delivery. Modified from (101).

\begin{tabular}{ll}
\hline Parameter & Properties \\
\hline Dose & Should be low $(<20 \mathrm{mg} /$ day $)$ \\
Half-life & 10 hours or less \\
Molecular weight & $<400 \mathrm{Da}$ \\
Partition coefficient & Log P $($ octanol-water coefficient $)$ between 1.0 and 4 \\
Skin permeability coefficient & $>0.5 \times 10^{-3} \mathrm{~cm} / \mathrm{h}$ \\
Skin reaction & Non irritating and non-sensitizing \\
Oral bioavailability & Low \\
Therapeutic index & Low \\
\hline
\end{tabular}

Table 4: Studies on PLO gel formulations for systemic and local deliveries (partial listing).

\begin{tabular}{|c|c|c|c|}
\hline Drug & $\begin{array}{l}\text { Study Model/ } \\
\text { Ex vivo skin model } \\
\text { (or) Experimental } \\
\text { participants }\end{array}$ & Study Methods & Results \\
\hline Methimazole & $\begin{array}{l}\text { Healthy cats; } n=6 \\
(3 \text { male, } 3 \text { female })\end{array}$ & $\begin{array}{l}\text { A randomized triple } \\
\text { crossover protocol to } \\
\text { determine bioavailability of } \\
\text { methimazole from PLO gel } \\
\text { and compared to i.v. and } \\
\text { oral routes } \\
\text { administration. }\end{array}$ & $\begin{array}{l}\text { Methimazole absorption by the }(67) \\
\text { transdermal route was poor and } \\
\text { variable relative to the i.v. and } \\
\text { p.o. routes. Only one cat showed } \\
100 \% \text { transdermal } \\
\text { bioavailability relative to p.o } \\
\text { route. }\end{array}$ \\
\hline
\end{tabular}


Table 4 Continued...

\begin{tabular}{|c|c|c|c|}
\hline Methimazole & $\begin{array}{l}\text { Cats diagnosed with } \\
\text { hyperthyroidism } \\
\mathrm{n}=44 \quad(17 \text { cats } \text { oral } \\
\text { group and } 27 \text { cats } \\
\text { transdermal group) }\end{array}$ & $\begin{array}{l}\text { To determine the safety and } \\
\text { efficacy of the transdermal } \\
\text { methimazole with oral } \\
\text { methimazole for the control } \\
\text { of hyperthyroidism in cats. }\end{array}$ & $\begin{array}{l}\text { Generally, efficacy of (71) } \\
\text { transdermal methimazole is not } \\
\text { as high as p.o methimazole after } \\
2 \text { weeks of treatment and it is } \\
\text { associated with far fewer GI side } \\
\text { effects compared to the oral } \\
\text { route. Also, it is a good } \\
\text { therapeutic alternative in the } \\
\text { treatment of feline } \\
\text { hyperthyroidism as it shows } \\
\text { same effect as oral dose after } 4 \\
\text { weeks of treatments. }\end{array}$ \\
\hline Methimazole & $\begin{array}{lr}\text { Retrospective } & \text { study } \\
\mathrm{n}=13 \quad \text { cats } & \text { with } \\
\text { hyperthyroidism } & \end{array}$ & $\begin{array}{l}\text { PLO gel was applied to the } \\
\text { inner pinna of the ear in } \\
\text { doses ranging from } 2.5 \\
\mathrm{mg} / \mathrm{cat} \mathrm{q} 24 \mathrm{~h} \text { to } 10.0 \\
\mathrm{mg} / \mathrm{cat} \mathrm{q} 12 \mathrm{~h} \text {. Clinical and } \\
\text { laboratory data from the } \\
\text { cats were retrospectively } \\
\text { evaluated by telephone } \\
\text { conversations with } \\
\text { the veterinarians who } \\
\text { managed the cases. }\end{array}$ & $\begin{array}{l}\text { Methimazole PLO gel showed } \\
\text { clinical improvement. No } \\
\text { adverse effects were noticed } \\
\text { after several months of treatment } \\
\text { with PLO gel. }\end{array}$ \\
\hline Methimazole & $\begin{array}{l}\text { Hyperthyroid cats } \\
\text { after once- and twice- } \\
\text { daily transdermal } \\
\text { methimazole }(n=20)\end{array}$ & $\begin{array}{l}\text { PLO gel of methimazole } \\
\text { was applied to the pinna of } \\
\text { the inner ear at a starting } \\
\text { dose of } 2.5 \mathrm{mg} / \mathrm{cat} \mathrm{q} 12 \mathrm{~h} \\
\text { (BID group, } 10 \text { cats) and } \\
5 \mathrm{mg} / \mathrm{cat} \mathrm{q} 24 \mathrm{~h} \text { (SID group, } \\
10 \text { cats). After } 1 \text { and } 3 \\
\text { weeks, T4 concentrations } \\
\text { were measured immediately } \\
\text { before and every } 2 \text { hours } \\
\text { after gel application over a } \\
\text { period of up to } 10 \text { hours. }\end{array}$ & $\begin{array}{l}\text { T4 concentrations were (78) } \\
\text { significantly decreased after } \\
\text { week } 1 \text { and } 3 \text { compared to } \\
\text { pretreatment concentrations in } \\
\text { both groups. A sustained } \\
\text { suppression of T4 concentration } \\
\text { during the 10-hour period, and } \\
\text { T4 concentrations immediately } \\
\text { before the next methimazole } \\
\text { treatment, were not significantly } \\
\text { different compared to any time } \\
\text { point after application, either in } \\
\text { the BID or SID groups. }\end{array}$ \\
\hline Methimazole & Feline ear skin & $\begin{array}{l}\text { To study the in vitro } \\
\text { percutaneous absorption of } \\
\text { methimazole in a lipophilic } \\
\text { vehicle and PLO gel in } \\
\text { feline ear skin. }\end{array}$ & $\begin{array}{l}\text { Methimazole was better } \\
\text { absorbed from the lipophilic } \\
\text { vehicle compared to } \\
\text { administration in the PLO gel }\end{array}$ \\
\hline Fluoxetine & Healthy cats $(n=4)$ & $\begin{array}{l}\text { Parallel study: } 3 \text { groups of } 4 \\
\text { cats to assess } \\
\text { bioavailability, } \\
\text { pharmacokinetics, and } \\
\text { safety of fluoxetine PLO gel } \\
\text { for transdermal delivery and } \\
\text { compare it to oral delivery. }\end{array}$ & $\begin{array}{l}\text { Fluoxetine PLO gel (15\%) } \\
\text { formulation showed good } \\
\text { absorption through the skin of } \\
\text { cats into the systemic } \\
\text { circulation. However, the } \\
\text { relative bioavailability for } \\
\text { transdermal administration is } \\
\text { approximately } 10 \% \text { compared to } \\
\text { the p.o. route }\end{array}$ \\
\hline
\end{tabular}


Table 4. Continued...

\begin{tabular}{|c|c|c|c|}
\hline Dexamethasone & $\begin{array}{l}\text { Healthy } \\
n=5\end{array}$ & $\begin{array}{l}\text { Pilot crossover study as } \\
\text { each cat received both } \\
\text { transdermal PLO gel and } \\
\text { oral treatments in a random } \\
\text { order to compare serum } \\
\text { concentration } \\
\text { dexamethasone after single } \\
\text { dose of both treatments. }\end{array}$ & $\begin{array}{l}\text { There is no significant } \\
\text { absorption of dexamethasone } \\
\text { after administration of PLO gel } \\
\text { as all samples were below the } \\
\text { limit of detection (LOD). }\end{array}$ \\
\hline Ketoprofen & 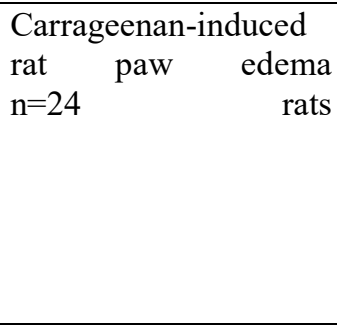 & $\begin{array}{l}\text { Evaluate and compare the in } \\
\text { vitro and in vivo anti- } \\
\text { inflammatory effects of the } \\
\text { ricinoleic acid PLO gel } \\
\text { system with isopropyl } \\
\text { palmitate PLO gel. } \\
\text { Ketoprofen was used as a } \\
\text { model drug. }\end{array}$ & $\begin{array}{l}\text { Both in vitro and in vivo studies } \\
\text { have shown better anti- } \\
\text { inflammatory property of } 10 \% \\
\text { ketoprofen ricinoleic acid PLO } \\
\text { gel compared to isopropyl } \\
\text { palmitate PLO gel. }\end{array}$ \\
\hline Ketoprofen & $\begin{array}{lr}\text { Healthy } & \text { participants, } \\
\mathrm{n}= & 8\end{array}$ & $\begin{array}{l}\text { Open-label crossover study } \\
\text { as the volunteers received } \\
\text { an oral ketoprofen capsule } \\
\text { or topical } 20 \% \text { ketoprofen } \\
\text { PLO }\end{array}$ & $\begin{array}{l}\text { When ketoprofen was (104) } \\
\text { administered as PLO gel, it had } \\
\text { low relative bioavailability and } \\
\text { high variability compared to oral } \\
\text { route. }\end{array}$ \\
\hline $\begin{array}{l}\text { Ketoprofen and } \\
\text { Testosterone }\end{array}$ & 3 human skin samples & $\begin{array}{l}\text { Testing in vitro and ex vivo } \\
\text { percutaneous absorption of } \\
\text { ketoprofen and testosterone } \\
\text { from PLO gel compared to } \\
\text { Pentravan cream by using } \\
\text { Franz-Diffusion cells. }\end{array}$ & $\begin{array}{l}\text { The absorption of Pentravan (105) } \\
\text { cream for both drugs was found } \\
\text { to be higher than PLO gel } \\
\text { formulations. }\end{array}$ \\
\hline Diclofenac & $\begin{array}{l}14 \text { patients with lateral } \\
\text { epicondylitis. }\end{array}$ & $\begin{array}{l}\text { A randomized, double- } \\
\text { blind, cross-over study to } \\
\text { assess the effectiveness of } \\
\text { diclofenac as a PLO gel for } \\
\text { treatment of lateral } \\
\text { epicondylitis administered } \\
\text { 3x daily for one week. }\end{array}$ & $\begin{array}{l}\text { A } 2 \% \text { diclofenac PLO gel (69) } \\
\text { provided an effective reduction } \\
\text { of pain associated with lateral } \\
\text { epicondylitis. }\end{array}$ \\
\hline Diclofenac & $\begin{array}{l}74 \text { patients with } \\
\text { osteoarthritis of the } \\
\text { knee. }\end{array}$ & $\begin{array}{l}\text { A double blind, } \\
\text { randomized, placebo, } \\
\text { designed as a parallel group } \\
\text { to evaluate using diclofenac } \\
\text { as a PLO gel for treating } \\
\text { osteoarthritis of the knee. }\end{array}$ & $\begin{array}{l}\text { There was a significant } \\
\text { improvement of quality of life of } \\
\text { osteoarthritis patients as they } \\
\text { experienced less pain after } \\
\text { diclofenac PLO gel } \\
\text { administration. }\end{array}$ \\
\hline Ondansetron & $\begin{array}{l}\text { Healthy participants, } \\
\mathrm{n}=12\end{array}$ & $\begin{array}{l}\text { To assess ondansetron PLO } \\
\text { gel for transdermal delivery } \\
\text { and assess inflammatory } \\
\text { and hyperalgesia. }\end{array}$ & $\begin{array}{l}\text { Topical application of PLO gel } \\
\text { reduced the inflammatory effect } \\
\text { induced by capsaicin injection. }\end{array}$ \\
\hline $\begin{array}{l}\text { Amitriptyline } \\
\text { and buspirone }\end{array}$ & Healthy cats, $n=6$ & $\begin{array}{l}\text { Crossover design study to } \\
\text { assess the relative } \\
\text { bioavailability } \\
\text { amitriptyline and buspirone } \\
\text { PLO gels compared to } \\
\text { single oral dose. }\end{array}$ & $\begin{array}{l}\text { Systemic absorption of }(107) \\
\text { amitriptyline and buspirone PLO } \\
\text { gels administered by the } \\
\text { transdermal route was poor } \\
\text { compared to oral route. }\end{array}$ \\
\hline
\end{tabular}


Table 4. Continued...

\begin{tabular}{|c|c|c|c|c|}
\hline Promethazine & $\begin{array}{l}\text { Healthy participants, } \\
\mathrm{n}=15\end{array}$ & $\begin{array}{l}\text { Randomized, open-label, } \\
\text { and crossover study to } \\
\text { assess the bioavailability of } \\
\text { promethazine PLO gel as } 15 \\
\text { subjects were administered } \\
\text { PLO gel and after } 21 \text { days, } \\
10 \text { of the subjects were } \\
\text { given promethazine as an } \\
\text { intravenous injection. }\end{array}$ & $\begin{array}{l}\text { Systemic absorption of topically } \\
\text { applied promethazine PLO gel } \\
\text { happened as the amount of the } \\
\text { drug was detected from plasma } \\
\text { samples. }\end{array}$ & (92) \\
\hline Morphine & $\begin{array}{l}\text { Human participants, } \\
\mathrm{n}=5\end{array}$ & $\begin{array}{l}\text { Randomized, placebo- } \\
\text { controlled, double-blind, } \\
\text { crossover study to evaluate } \\
\text { the bioavailability of } \\
\text { morphine administered as } \\
\text { topical PLO gel or } \\
\text { subcutaneously. }\end{array}$ & $\begin{array}{l}\text { The amount of morphine could } \\
\text { not be quantified after PLO gel } \\
\text { administration, which is } \\
\text { considered as low bioavailability } \\
\text { compared to subcutaneous route. }\end{array}$ & $(65)$ \\
\hline Methadone & $\begin{array}{l}10 \text { patients } \\
\text { administered PLO gel, } \\
5 \quad \text { patients } \\
\text { administered orally, } 1 \\
\text { patient was given } \\
\text { placebo topically }\end{array}$ & $\begin{array}{l}\text { To measure blood } \\
\text { methadone levels achieved } \\
\text { after topical PLO gel and } \\
\text { oral administration to } \\
\text { hospice patients. }\end{array}$ & $\begin{array}{l}\text { Methadone PLO gel in doses } \\
\text { less than } 45 \mathrm{mg} / \text { day did not } \\
\text { result in trough methadone blood } \\
\text { concentrations associated with } \\
\text { analgesia. Also, the placebo } \\
\text { response may explain the } \\
\text { perceived benefit of methadone } \\
\text { PLO gel in doses less than } 45 \\
\mathrm{mg} / \text { day. The evaluation of } \\
\text { systemic absorption of } \\
\text { methadone -PLO gel in doses } \\
\text { more than } 45 \mathrm{mg} / \text { day is } \\
\text { guaranteed. }\end{array}$ & (93) \\
\hline $\mathrm{ABH}$ & $\begin{array}{l}\text { Healthy } \\
n=10\end{array}$ & $\begin{array}{l}\text { In vivo study using ABH } \\
\text { PLO gel formulation, which } \\
\text { is composed of lorazepam } \\
\left(\text { Ativan }{ }^{\circledR}\right) \text {, } \\
\text { diphenhydramine } \\
\left(\text { Benadryl }{ }^{\circledR}\right), \quad \text { and } \\
\text { haloperidol }\left(\mathrm{Haldol}^{\circledR}\right) \\
\text { incorporated in PLO } \\
\text { applied to healthy } \\
\text { volunteers' wrists. }\end{array}$ & $\begin{array}{l}\text { Sufficient absorption of drugs } \\
\text { was not observed from the PLO } \\
\text { gel. All drug concentration } \\
\text { measurements showed sub- } \\
\text { therapeutic values. }\end{array}$ & $(95)$ \\
\hline Chlorpromazine & $\begin{array}{l}\text { Human participants, } \\
\mathrm{n}=11\end{array}$ & $\begin{array}{l}25 \mathrm{mg} \text { chlorpromazine } \mathrm{HCl} \text { in } \\
\text { PLO gel was administered to } \\
10 \text { subjects' wrists and } 100 \mathrm{mg} \\
\text { chlorpromazine administered } \\
\text { to one subject's wrist with the } \\
\text { goal to evaluate the absorption } \\
\text { of the drug transdermally. }\end{array}$ & $\begin{array}{l}\text { All samples were under limit of } \\
\text { detection, which indicated that } \\
\text { chlorpromazine would not } \\
\text { permeate through the skin } \\
\text { membrane. }\end{array}$ & (66) \\
\hline
\end{tabular}

Flurbiprofen Dialysis membrane Flurbiprofen PLO gel was and excised dorsal rat formulated and in vitro skin permeability was studied with Keshary-Chien diffusion cells. Also, in vivo study with carrageenan-induced rat paw edema model and skin
The permeability profile with (108) dialysis membrane was $70 \%$ more than the excised skin. Also, it has shown anti-inflammatory effects on animal models. 
Table 4. Continued...

irritation study was used.

\begin{tabular}{|c|c|c|c|c|}
\hline $\begin{array}{l}\text { Micronized } \\
\text { testosterone in } \\
\text { PLO gel }\end{array}$ & $\begin{array}{l}\text { Human participants, } \\
\mathrm{n}=22\end{array}$ & $\begin{array}{l}\text { Evaluation of systemic } \\
\text { delivery of hormone after } \\
\text { applying } 10 \% \text { testosterone } \\
\text { PLO gel. }\end{array}$ & $\begin{array}{l}\text { Total amount of testosterone was } \\
\text { found to increase as the hormone } \\
\text { permeated through the skin after } \\
\text { topical application. }\end{array}$ & $(109)$ \\
\hline Propolis & Rat abdominal skin & $\begin{array}{l}\text { PLO gel of propolis was } \\
\text { formulated to improve its } \\
\text { availability } \\
\text { antimicrobial } \\
\text { and } \\
\text { activity. }\end{array}$ & $\begin{array}{l}\text { The formula containing } 3 \% \\
\text { lecithin and } 20 \% \text { pluronic F } 127 \\
\text { exhibited superior skin } \\
\text { permeation and antimicrobial } \\
\text { activity over propolis suspension } \\
\text { in water. }\end{array}$ & $(21)$ \\
\hline $\begin{array}{l}\text { Ketoprofen and } \\
\text { Dexamethasone }\end{array}$ & $\begin{array}{l}\text { Bovine ear for } \\
\text { dexamethasone and } \\
\text { porcine stomach tissue } \\
\text { for ketoprofen }\end{array}$ & $\begin{array}{l}\text { PLO gel prepared using } \\
\text { ricinoleic acid as the oil } \\
\text { phase was compared to } \\
\text { isopropyl palmitate PLO } \\
\text { gel. The optimized PLO gel } \\
\text { with ricinoleic acid was } \\
\text { further evaluated using } \\
\text { ketoprofen }(10 \%) \text { and } \\
\text { dexamethasone }(0.5 \%) \text { as } \\
\text { model drugs. }\end{array}$ & $\begin{array}{l}\text { The penetration profile of } \\
\text { dexamethasone was similar to } \\
\text { both the PLO gels, while the } \\
\text { permeability for ketoprofen from } \\
\text { PLO gel containing ricinoleic } \\
\text { acid was found to be three times } \\
\text { higher as compared to the } \\
\text { control formulation. }\end{array}$ & $(110)$ \\
\hline Dexamethasone & $\begin{array}{l}\text { New Zealand White } \\
(\mathrm{NZW}) \text { albino adult } \\
\text { male rabbits }\end{array}$ & $\begin{array}{l}\text { Dexamethasone PLO gel } \\
\text { was applied transdermally } \\
\text { to the outside of the eyelid } \\
\text { skin. Rabbits } \\
\text { sacrificed at regular time } \\
\text { intervals } \\
\text { dexamethasone } \\
\text { concentrations } \\
\text { analyzed in and } \\
\text { segment were } \\
\text { Maxidex }{ }^{\circledR} \text { eye drops were } \\
\text { used as a control. }\end{array}$ & $\begin{array}{l}\text { PLO gel formulation resulted in } \\
\text { constant dexamethasone } \\
\text { concentrations in the anterior } \\
\text { segment tissues for up to } 24 \mathrm{~h} \text {, } \\
\text { which was equivalent to or } \\
\text { higher than Maxidex }{ }^{\circledR} \text { eye drops. }\end{array}$ & (111) \\
\hline Ketoprofen & $\begin{array}{l}\text { Carrageenan-induced } \\
\text { rat paw edema model }\end{array}$ & $\begin{array}{l}\text { In vivo anti-inflammatory } \\
\text { activity of ricinoleic acid } \\
\text { PLO gel containing } 10 \% \\
\text { ketoprofen was evaluated } \\
\text { and compared to the } \\
\text { isopropyl palmitate PLO gel } \\
\text { in a carrageenan-induced rat } \\
\text { paw edema model. }\end{array}$ & $\begin{array}{l}\text { Ricinoleic acid PLO gel of } \\
\text { ketoprofen was significantly } \\
\text { more effective in reducing pain } \\
\text { and edema when compared to } \\
\text { the isopropyl palmitate PLO } \\
\text { gel. }\end{array}$ & $(112)$ \\
\hline Sinomenine & $\begin{array}{l}\text { Microdialysis in male } \\
\text { Sprague-Dawley rats }\end{array}$ & $\begin{array}{l}\text { To evaluate the permeability of } \\
\text { the optimized PLO gel of } \\
\text { sinomenine in vitro and in vivo. }\end{array}$ & $\begin{array}{l}\text { This study reported a significant } \\
\text { increase in the permeation of } \\
\text { sinomenine from PLO gels }\end{array}$ & $(31)$ \\
\hline $\begin{array}{l}\text { Diltiazem } \\
\text { hydrochloride }\end{array}$ & Rats & $\begin{array}{l}\text { PLO gels of diltiazem } \\
\text { hydrochloride were developed } \\
\text { with varying ratios of organic } \\
\text { phase to aqueous phase and } \\
\text { with varying concentrations of } \\
\text { soya lecithin in isopropyl } \\
\text { myristate and pluronic in } \\
\text { aqueous phase and } \\
\text { characterized for in vitro } \\
\text { parameters and ex vivo } \\
\text { permeation study. }\end{array}$ & & (113) \\
\hline
\end{tabular}


Table 4. Continued...

\begin{tabular}{lllll}
\hline $\begin{array}{l}\text { Quetiapine and } \\
\text { venlafaxine }\end{array}$ & $\begin{array}{l}\text { Patients with advanced } \\
\text { dementia }\end{array}$ & $\begin{array}{l}\text { PLO gels of quetiapine and } \\
\text { venlafaxine were tested in } \\
\text { dementia patients. }\end{array}$ & $\begin{array}{l}\text { All patients showed mild to } \\
\text { marked improvement } \\
\text { psychiatric symptoms such as } \\
\text { agitation, aggressive behavior } \\
\text { and depression. }\end{array}$ \\
\hline Ketoprofen & $\begin{array}{l}\text { Ex vivo permeation in } \\
\text { human cadaver trunk } \\
\text { skin }\end{array}$ & $\begin{array}{l}\text { Percutaneous absorption of } \\
10 \% \text { ketoprofen from PLO } \\
\text { gel and Lipoderm in human } \\
\text { cadaver trunk skin. }\end{array}$ & $\begin{array}{l}\text { Ketoprofen in phospholipid base } \\
\text { show higher and faster } \\
\text { absorption than PLO gel. }\end{array}$ \\
\hline
\end{tabular}

PLO gels have been found to be non-irritating to the skin, odorless and allow the quick passage of drug through the skin. They are also known to be effective in moisturizing and revitalizing keratin-like tissues such as the hair, fingernails and skin. These gels consist of reversed polymer-like micelles, which evolve from spherical micelles seen initially, which agglomerate to form a temporal threedimensional network in the bulk phase and are obtained by the dissolution of trace amounts of water in a non-aqueous solution $(19,38,42)$. Some in vivo studies have revealed the ability of PLO gels to be excellent drug carriers with penetration enhancement ability. Significant drug penetration into the systemic circulation was observed on repeated topical application of methimazole to the inner pinna of healthy cats suffering from hyperthyroidism, which was not observed after a single application (67). This was assumed to be a consequence of lowered resistance to the drug penetration caused by the exfoliation of stratum corneum produced by the lecithin component in the gel (62). According to Giordano and his co-workers, a topical gel formulation of ondansetron showed a greater reduction in pain after a single application in healthy human volunteers for whom mechanical hyperalgesia and flare were stimulated by the intradermal administration of capsaicin (68). PLO gels were also reported to be effective in producing a local action, especially in the case of nonsteroidal anti-inflammatory drugs (NSAIDs). Diclofenac-loaded PLO gel was found to ameliorate pain to a greater extent, along with enhancement in wrist extension strength, when used to treat osteoarthritis of the knee and lateral epicondylitis (69). Acetaminophen-loaded PLO gel was found to be beneficial for cancer patients in a hospice setting, when applied transdermally (70). Methimazole PLO gel, when applied to the inner pinna of cats suffering from hyperthyroidism, lowered gastrointestinal adverse effects compared to orally administered methimazole. However, the transdermal application did not exhibit a higher bioavailability than the orally administered drug (71). PLO-based gel loaded with fish oils, eicosapentaenoic acid (EPA), and docosahexaenoic acid (DHA) was capable of delivering the oils transdermally by a fixed repeated dosage regimen rather than by the administration of a finite dose, while retaining a part of these highly lipophilic molecules within the gel matrix. Delivery of ketoprofen through PLO gels was also observed in the same study, where the drug molecules were retained in the matrix to a lesser extent (72). Despite the incorporation of several drugs into PLO gels, there is still a lack of in depth understanding on its properties and mechanisms by which PLO gels promote drug penetration. These concerns have prevented PLO gels from becoming a mainstream dosage form.

\section{Patents related PLO gels in drug delivery}

The patents related to the use of PLO gels for local and systemic delivery of drugs are limited. Patent WO2008070728 A2, issued to Connor and Haine (73), describes the transdermal delivery to the eye with a therapeutically effective amount of progestagen, a testosterone, in treating dry eye. A PLO gel of progestagen is applied in required amounts to the palpebral part of the eye and/or ocular surface. As stated in the patent, transdermal application of drugs provides effective treatment by reducing side effects caused by systemic use such as upset stomach, 
cramps, breast tenderness, drowsiness, dizziness, headache, migraine headache, vomiting, diarrhea, constipation, fatigue, skin rash, and lower levels of high density lipoprotein. The transdermal treatment of progestagen PLO gel can generate functional regions of lacrimal tissue and thereby correct certain eye conditions such as dry eye by enhancing tear output. None of the patients reported side effects or allergic reactions from the use of progesterone cream (73).

As per patent US20050196433A1 (74), transdermal pharmaceutical compositions are used for preventing magnesium deficiency or imbalances associated with magnesium deficiency including acute myocardial infarction, arteriosclerosis, atherosclerosis, asthma, cardiac arrhythmias, chronic fatigue syndrome, constipation, cramping, diabetes, dysautonomia, fibromyalgia, high cholesterol, hypertension, irritable bowel syndrome, kidney stones, mitral valve prolapse, migraines, muscle spasms, preeclampsia, premenstrual syndrome, and osteoporosis. The proposed transdermal pharmaceutical composition contained an acceptable salt of magnesium in PLO gel that exhibits optimal skin absorption characteristics and could be used to prevent magnesium deficiency or imbalances caused by magnesium deficiency (74).

According to patent US20080311167A1 (75), active ingredients such as a lipid, fatty acid ester, natural wax, sterol, or combinations contained in a lipophilic vehicle could be used for the amelioration or prevention of pain or the sequelae of pain. This patent highlighted the use of organogels prepared using excipients that are amphiphilic, hydrophobic, lipophilic and/or surface active. In addition to active ingredients, the formulation was composed of Pluronic 20\% with $750 \mathrm{mg}$ lactose, VanPen and PLO gel (combination of $25 \%$ soy lecithin in isopropyl myristate to $75 \%$ pluronic gel). Patent CA2493947A1 (76) disclosed Arthro Gel and Syner Gel for pain relief when topically applied to areas of arthritis, tendonitis and sports related injuries. Arthro Gel and Syner Gel were mixed in a special ratio to obtain a unique and effective combination. Arthro Gel contained 10\% glucosamine sulfate, PLO gel, 70\% isopropyl alcohol and propylene glycol, while Syner Gel contained $9 \%$ glucosamine sulfate, $1 \%$ ibuprofen, PLO gel, 70\% isopropyl alcohol and propylene glycol. Syner Gel is said to contain an optimal ratio of both glucosamine sulfate and ibuprofen to achieve optimal topical pain relief for the above stated conditions.

Both of the above products contain optimal concentrations of known active ingredients to help relieve pain among tendonitis and osteoarthritis sufferers.

US patent 20050042241A1 (77) claimed a topical cream applied to the skin for relieving pain of arthritis, tendonitis, and bursitis. The cream is designed to deliver pain and antiinflammatory medications to inflamed joints, bursae and tendons directly through the skin. This patent described a formulation of dimethylsufloxide (DMSO), a penetration enhancer, and PLO gel containing diphenhydramine and ketoprofen to reduce pain and inflammation through the intact skin. US patent 20120283332 (78) described transdermal metformin as an alternative for patients with insulin resistance. The claimed preparation of metformin was comprising of at least one penetration enhancer selected from PLO gel, DMSO, lecithin, lecithin isopropyl palmitate and one or more of an alkali metal alkyl sulfate, etc. This patent described metformin $200 \mathrm{mg} / \mathrm{ml}$ formulations in 30\% PLO gel, 20\% PLO gel, $10 \%$ PLO gel/DMSO and 20\% PLO gel/DMSO.

The patent literature provides insight into discoveries that are mostly translated into pharmaceutical products. Although PLO gels have been known for more than 25 years, very few patents related to the use of PLO gels in drug delivery are found in the literature. This could be mainly due to the motivation among the scientific community, both at academic and industrial levels to develop novel technologies rather than using conventional dosage forms such as ointments, creams and gels.

\section{Controversies surrounding PLO gel}

PLO gels are very helpful for patients with swallowing difficulties and for patients suffering from acute and delayed chemotherapy-induced nausea and vomiting. In some cases, PLO gel formulations are applied with a goal of cutaneous absorption to achieve systemic activity (54). To some extent, PLO gels are capable of enhancing the drug permeability through the stratum corneum and delivering the 
drug into systemic circulation via dermal blood flow. However, certain controversy exists regarding the use of some compounded drug preparations. While some reports have suggested the beneficial effects of drugs delivered in PLO gels, others question their safety and efficacy. Like other transdermal dosage forms, the success of PLO gels depends on potency, molecular weight and $\log P$ value of drugs, to some extent (79). Marketed transdermal products undergo thorough scrutiny by the Food and Drug Administration (FDA) for demonstration of efficacy. On the other hand, PLO gels are prepared by compounding pharmacies, and these products do not require FDA approval (65). Most compounding pharmacies advertise their willingness to provide formulations without proper clinical data and evidence-based studies regarding the efficacy of PLO gels (6). Recently, the effectiveness and absorption of drugs into the bloodstream from PLO gel studies have been investigated by many groups on a case-by-case basis. In this section, we intend to highlight some observational studies that demonstrated the effectiveness of PLO gels, along with clinical studies that negate the drug absorption of extemporaneously compounded PLO gel administered topically to patients.

\section{Promethazine}

Promethazine $\mathrm{HCl}$ is a phenothiazine derivative widely used for treating nausea and vomiting in both adults and children. Most antiemetics are delivered via oral, injectable, and rectal routes; however, the transdermal route could be a better alternative for hospice patients in the end stages of life (80). In one study, researchers performed an in vivo study on 15 healthy humans at a tertiary care facility to determine the bioavailability of promethazine in a topical PLO gel. Fifty milligrams of promethazine in PLO gel was applied once onto the skin of the nondominant wrist, and the application area was covered with an adhesive bandage. The results were compared to a single dose of intravenous promethazine $25 \mathrm{mg}$. Topical promethazine resulted in lower systemic concentrations when compared to injectable administration, with an absolute bioavailability of $2 \%$. The mean areas under the curves after topical and intravenous administrations were found to be $16.63 \mathrm{ng} . \mathrm{mL} / \mathrm{h}$ and 407.15 ng.mL/h, respectively. All patients who received intravenous dose experienced sedation, while only $50 \%$ of the subjects who received topical promethazine experienced sedation. Despite low serum concentrations from topical promethazine PLO gel, this study demonstrated systemic concentrations after topical application (81). This study suggested further clinical studies to identify the antiemetic efficacy of promethazine PLO gel in a larger patient population.

\section{Morphine}

Morphine is an opioid analgesic drug widely used for treating cancer-related pain. Elderly patients with swallowing difficulties or intestinal obstruction require transdermal delivery of morphine. Topical administration of $0.1 \%$ morphine hydrochloride loaded into a PLO gel has been reported to provide rapid pain relief for patients receiving palliative care $(82,83)$. A few studies have been conducted to evaluate both local and systemic effects of morphine from PLO gels. Wilken et al. (84) studied the analgesic response of topical morphine to control chronic pain and also detected the presence of morphine in urine. Patients were instructed to apply the morphine in PLO gel (10 $\mathrm{mg} / \mathrm{ml}$ ) to either the upper arm or subclavicular area twice daily. Subjects continued the topical morphine treatment for 32 days until a pain goal of $1-2 / 10$ was achieved. After attaining the required pain control, a 24-hour urine collection was obtained and morphine levels were analyzed. This study concluded that topical morphine provides good analgesic response in chronic arthritic patients, which was further supported by urinary morphine concentrations ranging from $31-191 \mathrm{ng} / \mathrm{mL}$. Based on this literature finding, PLO gel formulation of morphine applied to the wrist has been considered as a suitable alternate for systemic delivery. However, studies published in subsequent years contradicted the above findings. In 2008, Paice et al. (65) studied the bioavailability of topically administered morphine in five healthy volunteers. One milliter of $10 \mathrm{mg} / \mathrm{mL}$ morphine PLO gel was applied to the wrist, and 17 blood samples were collected between 5 minutes and 10 hours after. The authors were unable to detect morphine in blood samples collected, and morphine concentration 
at all-time points was below the limit of quantification, $\quad 0.5 \mathrm{ng} / \mathrm{mL}$. A morphine concentration of $10 \mathrm{ng} / \mathrm{mL}$ is needed for effective analgesic action (85). The authors concluded that PLO gel of morphine is unlikely to provide systemic concentrations or relief to cancer-related pain. A different study conducted on human cadaver skin reported similar findings and concluded that morphine is a poor candidate for transdermal drug delivery (86). Even studies in animal models could not obtain drug concentrations in plasma (87). The complete lack of bioavailability of topically administered morphine has been attributed to the intact epidermis and the inability of the PLO gel to enhance the permeation of morphine (87-89).

\section{Methadone}

Methadone is an opioid medication popularly used as an analgesic for pain management among hospice patients with dementia. A transdermal formulation of methadone in PLO gel became available through compounding pharmacies based on anecdotal reports from the nursing staff. An in vitro study evaluated the absorption of methadone through mouse and human skin. Methadone absorption was found to be higher in the hairless skin of mice than in the human cadaver skin (90). This study demonstrated the feasibility of transdermal methadone administration. Despite the rampant use of transdermal methadone PLO gel among hospice patients, no clinical studies were conducted assessing the systemic absorption or clinical efficacy of topical methadone for systemic pain until recently. In 2011, Sylvester et al. investigated the serum concentrations of methadone following topical administration (10 $45 \mathrm{mg} /$ day in a PLO gel) in 10 hospice patients and oral administration (15-40 mg/day) in 5 patients. Two steady-state serum levels were determined in the patients after topical administration. This study aimed to compare methadone serum concentrations after oral and topical application. It was reported that 18 of 20 serum methadone concentrations after topical administration were below $10 \mathrm{ng} / \mathrm{mL}$, while 25.8 $\mathrm{ng} / \mathrm{mL}$ was observed in 1 subject who received the highest topical dose $(45 \mathrm{mg} /$ day $)$. These serum concentrations after topical application are considerably less than serum concentrations after oral methadone administration, which ranged from 62 to $393 \mathrm{ng} / \mathrm{mL}$ (91). This study concluded that methadone applied topically as a PLO gel in doses of $<45 \mathrm{mg} /$ day failed to produce required concentrations in plasma, and further clinical studies are needed for doses $>45$ $\mathrm{mg} /$ day.

\section{ABH gels}

The quality of life of a hospice patient is greatly diminished by the disease state and medicationrelated side effects. The physical condition of patients and medication-related side effects such as nausea and vomiting demand the creation and use of alternative products for such patients. PLO gels containing a combination of antiemetic drugs such as lorazepam (A), diphenhydramine (B), and haloperidol $(\mathrm{H})$, also known as $\mathrm{ABH}$ gel, have been widely used in treating nausea and vomiting. They are not readily available on the market and must be formulated by a compounding pharmacist. A usual dose would be $1 \mathrm{~g}$ or $(1 \mathrm{~mL})$ and is administered to the inner wrist skin every four to six hours. The letter "A" is Ativan ${ }^{\circledR}$, which is known by its generic name, lorazepam. The antiemetic activity of benzodiazepines is not clear, yet they repress the limbic system and decrease cortical central nervous system input into the vomiting center of the central nervous system. The letter " $B$ " is Benadryl, which is known by its generic name, diphenhydramine. It functions as an antihistamine and anticholinergic agent and diminishes the activity of the vestibular system. Also, diphenhydramine can diminish extrapyramidal antagonistic impacts from dopamine antagonists. The letter " $\mathrm{H}$ " represents Haldol ${ }^{\circledR}$, known by its generic name, haloperidol, a strong dopamine antagonist. $\mathrm{ABH}$ gel is actually well tolerated by a high percentage of patients. If $\mathrm{ABH}$ gel is powerful at alleviating nausea, it could be an essential and moderately less costly treatment. In one observational study, two trials were conducted in adult patients suffering from chemotherapyinduced nausea and vomiting. In Trial I, topical administration of $\mathrm{ABH}$ gel decreased nausea and vomiting in 17 out of 23 patients with chemotherapy-induced nausea and vomiting. Trial II was carried out in 10 patients, and the treatment was found to be effective in all patients (64). In one study, 10 healthy volunteers between the ages of 25 and 58 were 
administered the standard $1.0 \mathrm{~mL}$ dose $\mathrm{ABH}$ gels on the volar surface of the wrists. One study tested the cutaneous absorption of $\mathrm{ABH}$ gel in healthy adults. In this study, none of the lorazepam (A) or haloperidol (H) was absorbed into the bloodstream, and diphenhydramine (B) had insufficient quantities to be effective for nausea and vomiting. No lorazepam or haloperidol was detected in blood samples collected after $0,30,60,90,120,180$, and 240 minutes, while diphenhydramine was detected in 5 out of 10 patients (92). Fletcher et al. (93) conducted a randomized, double-blind, placebocontrolled, crossover, noninferiority clinical trial to study the effectiveness of $\mathrm{ABH}$ gel compared to placebo in cancer patients with nausea. This study concluded that $\mathrm{ABH}$ gel did not decrease vomiting events better than placebo $(\mathrm{P}=0.34)$ and that $\mathrm{ABH}$ gel should not be used in cancer patients experiencing nausea in its current form. Similar results have been published with ABHR gels. The letter " $R$ " is Reglan ${ }^{\circledR}$, known by its generic name, metoclopramide. This agent works both as a dopamine antagonist and to enhance slowed GIT transit time. The side effects anticipated from this mixture are generally drowsiness, lethargy, confusion and muscle jerks. The above discussion clearly indicates that investigative studies looking at the absorption and plasma concentrations of medications after topical administration do not support the results from observational studies.

\section{Chlorpromazine}

Chlorpromazine is a dopamine antagonist with additional anti-adrenergic, anti-

serotonergic, anti-cholinergic and anti-

histaminergic properties. It is widely used in the treatment of nausea and vomiting. The commercially available oral liquid of chlorpromazine (Thorazine ${ }^{\circledR}$ ) was discontinued due to safety reasons $(66,94)$. Since then, there has been an increased use of chlorpromazine PLO gel for managing symptoms such as nausea, vomiting, agitation and delirium. However, there is no supporting data from clinical trials determining the transdermal absorption of chlorpromazine until the recent past. In an in vitro study, the authors studied the permeability of chlorpromazine across pig skin, with the absorption following passive diffusion and iontophoresis. Iontophoresis procedure involves using a gentle electric current to improve skin penetration of drugs. This work concluded that iontophoresis is a useful tool in improving the transdermal delivery of chlorpromazine for treating chronic psychosis (95). Weiland et al. (66) studied the transdermal absorption of chlorpromazine PLO gel in 11 healthy adults between 18 and 70 years of age. A dose of $25 \mathrm{mg}$ of chlorpromazine in PLO gel was applied to wrists, and $100 \mathrm{mg}$ was applied to 1 subject's wrist. This study concluded that chlorpromazine was below the detection limit $(10 \mathrm{ng} / \mathrm{mL})$ in all 11 subjects' blood samples at 1,2 , and $4 \mathrm{~h}$ after topical application, and topical chlorpromazine PLO gel may not be an effective treatment. These intriguing results prompted us to investigate the percutaneous absorption of chlorpromazine hydrochloride from PLO gel (96). In vitro percutaneous absorption of chlorpromazine hydrochloride through porcine ear and human abdominal skin from PLO gels was carried out, and the theoretical plasma concentration of chlorpromazine was determined from flux values. The results from our study corroborate the published results by Weiland et al., (66). The lag times of chlorpromazine hydrochloride for pure drug solution and PLO gel varied between $2.5-4 \mathrm{~h}$, which might be a reason for the delay in the onset of plasma concentrations in human participants. Theoretical $\mathrm{C}_{\mathrm{ss}}$ of chlorpromazine from the pure drug and PLO gel were found to be far below the required steady state concentration for therapeutic activity. Based on the permeability data across the human abdominal skin, it is concluded that chlorpromazine hydrochloride does not have sufficient permeability through the skin to attain the required systemic concentrations needed to effectively manage nausea and vomiting in hospice patients (96).

\section{CONCLUSION}

With the advancement of topical and transdermal drug delivery, organogels have manifested as one of the most effective bases for drugs that previously had to be administered by oral routes or through injections. There has been a steady rise in exploring the possible uses of PLO gels since the early 90s, especially by compounding pharmacies. PLO gels are widely used by clinicians and veterinarians to deliver 
drugs via the transdermal route for systemic and local effects. Recently, some research articles have questioned the efficacy of PLO gels in percutaneous absorption of drugs. The lack of beneficial effects from transdermal PLO gels may be due to improper preparation technique and failure to select a suitable drug with an ideal molecular weight, log P value and potency. PLO gels should only be considered as a transdermal delivery option and should be utilized accordingly when appropriate, based on the physicochemical properties of drugs, dose and application site. There is a clear need for further research to determine the percutaneous absorption of drug-loaded PLO gels on a caseby-case basis for optimal patient care and therapeutic outcomes. Further research based on blinded and placebo controlled PK/PD studies, which yield tangible outcomes, should be conducted to assess the efficacy of PLO gels rather than observational studies.

\section{ACKNOWLEDGEMENTS}

This work was partially supported by the International Academy of Compounding Pharmacists (IACP) foundation grant. Parts of this work were first published in its full form by Ms. Sindhu Prabha Bonam and Mr. Hashem Alsaab as their thesis work.

\section{DECLARATION OF INTEREST}

The authors declare no conflicts of interests.

\section{REFERENCES}

1. Ueda CT, Shah VP, Derdzinski K, Ewing G, Flynn G, Maibach H, et al., editors. Topical and transdermal drug products. Pharmacopeial Forum; 2009.

2. Vintiloiu A, Leroux J-C. Organogels and their use in drug delivery-a review. Journal of Controlled Release. 2008;125(3):179-92.

3. Murdan S. Organogels in drug delivery. Expert opinion on drug delivery. 2005;2(3):489-505.

4. Terech P, Weiss RG. Low molecular mass gelators of organic liquids and the properties of their gels. Chemical reviews. 1997;97(8):3133-60.

5. Hill K, Mills P, Jones B, Bolwell C, Aberdein D, Chambers J. Percutaneous absorption of methimazole: an in vitro study of the absorption pharmacokinetics for two different vehicles. Journal of veterinary pharmacology and therapeutics. 2015;38(6):581-9.

6. Scott DW, Miller Jr WH, Griffin CE. Chapter 3 - Dermatologic Therapy. Muller \& Kirk's Small Animal Dermatology (Sixth Edition). Philadelphia: W.B. Saunders; 2001. p. 207-73.

7. A.S. Hickey NAP. Mesh size and diffusive characteristics of semicrystalline poly(vinyl alcohol) membranes prepared by freezing/ thawing techniques. J Membr Sci 107. (1995):229 - 37.

8. N.A. Peppas NKM. Ultrapure poly(vinyl alcohol) hydrogels with mucoadhesive drug delivery characteristics. Eur J Pharm Biopharm 43. (1997):51 - 8.

9. Peppas NA. Biomaterials science: an introduction to materials in medicine. In: Ratner BD, Hoffman AS, Schoen FJ, Lemons JE, editors.: Academic press; 2004. p. 100-6.

10. Thomas M, Cornelius W, Holroyd M. Topical administration of psychotropic medications in pluronic lecithin organogel to treat patients with dementia: A retrospective observational study. Marshall Journal of Medicine. 2015;1(1):4.

11. Bassani AS, Banov D, Phan H. Characterization of the Percutaneous Absorption of Ketoprofen Using the Franz Skin Finite Dose Model. Postgraduate medicine. 2016(just-accepted).

12. P.J. Flory JR. Statistical mechanics of crosslinked polymer networks. II. Swelling. J Chem Phys 11. (1943):521 - 6.

13. Flory PJ. Principles of Polymer Chemistry. Cornell University Press, Ithaca, NY. 1953.

14. P.J. Flory. Statistical mechanics of swelling of network structures. J Chem Phys 18. (1950) 108-11.

15. B.D. Ratner ASH. Synthetic hydrogels for biomedical applications, in: J.D. Andrade (Ed.), Hydrogels for Medical and Related Applications,. ACS Symposium Series, No 31, American Chemical Society, Washington, DC. 1976:1 - 36.

16. Peppas NA, . Hydrogels in Medicine. CRS Press, Boca Raton, FL. 1986.

17. N.A. Peppas RL. New challenges in biomaterials,. Science 263 (1994):1715 -20.

18. Park K. Controlled Release: Challenges and Strategies. American Chemical Society, Washington, DC. 1997.

19. Willimann H, Walde P, Luisi P, Gazzaniga A, Stroppolo F. Lecithin organogel as matrix for transdermal transport of drugs. Journal of pharmaceutical sciences. 1992;81(9):871-4. 
20. Lupi FR, Gabriele D, Greco V, Baldino N, Seta L, de Cindio B. A rheological characterisation of an olive oil/fatty alcohols organogel. Food Research International. 2013 5//;51(2):510-7.

21. Balata G, El Nahas HM, Radwan S. Propolis organogel as a novel topical delivery system for treating wounds. Drug delivery. 2014;21(1):55-61.

22. Couffin-Hoarau A-C, Motulsky A, Delmas P, Leroux J-C. In situ-forming pharmaceutical organogels based on the self-assembly of Lalanine derivatives. Pharmaceutical research. 2004;21(3):454-7.

23. Raghavan SR, Douglas JF. The conundrum of gel formation by molecular nanofibers, wormlike micelles, and filamentous proteins: gelation without cross-links? Soft Matter. 2012;8(33):8539-46.

24. Hirst AR, Coates IA, Boucheteau TR, Miravet JF, Escuder B, Castelletto V, et al. Lowmolecular-weight gelators: elucidating the principles of gelation based on gelator solubility and a cooperative self-assembly model. Journal of the American Chemical Society. 2008;130(28):9113-21.

25. Brizard A, Oda R, Huc I. Chirality effects in self-assembled fibrillar networks. Low Molecular Mass Gelator: Springer; 2005. p. 167-218.

26. Fuhrhop JH, Helfrich W. Fluid and solid fibers made of lipid molecular bilayers. Chemical reviews. 1993;93(4):1565-82.

27. Gronwald O, Shinkai S. Sugar-Integrated Gelators of Organic Solvents. Chemistry-A European Journal. 2001;7(20):4328-34.

28. Vintiloiu A, Leroux J-C. Organogels and their use in drug delivery - A review. Journal of Controlled Release. 2008 2/11/;125(3):179-92.

29. Shchipunov YA, Shumilina E, Hoffmann H. Lecithin organogels with n-alkyl-D-glucosides and n-alkly-D-lactobionamide. Colloid and Polymer Science. 1998;276(4):368-72.

30. Almeida I, Bahia M. Comparison of the mechanical properties of two oleogels. Rheo pt. 2005;5:12-8.

31. Ba W, Li Z, Wang L, Wang D, Liao W, Fan $\mathrm{W}$, et al. Optimization and evaluation of pluronic lecithin organogels as a transdermal delivery vehicle for sinomenine. Pharmaceutical development and technology. 2015:1-11.

32. Schurtenberger P, Scartazzini R, Magid LJ, Leser ME, Luisi PL. Structural and dynamic properties of polymer-like reverse micelles. Journal of Physical Chemistry. 1990;94(9):3695-701.
33. Shchipunov YA, Shumilina E. Lecithin organogels: role of polar solvent and nature of intermolecular interactions. Colloid journal of the Russian Academy of Sciences. 1996;58(1):117-25.

34. Schurtenberger P, Cavaco C. Polymer-like lecithin reverse micelles. 1. A light scattering study. Langmuir. 1994;10(1):100-8.

35. Shchipunov YA, Dürrschmidt T, Hoffmann H. Electrorheological Effects in Lecithin Organogels with Water and Glycerol. Journal of colloid and interface science. 1999;212(2):390-401.

36. Kumar R, Katare OP. Lecithin organogels as a potential phospholipid-structured system for topical drug delivery: a review. AAPS PharmSciTech. 2005;6(2):E298-E310.

37. Walde P, Giuliani AM, Boicelli CA, Luisi PL. Phospholipid-based reverse micelles. Chemistry and physics of lipids. 1990;53(4):265-88.

38. Shchipunov YA, Shumilina EV. Lecithin bridging by hydrogen bonds in the organogel. Materials Science and Engineering: C. 1995;3(1):43-50.

39. Shchipunov YA, Schmiedel P. Phase behavior of lecithin at the oil/water interface. Langmuir. 1996;12(26):6443-5.

40. Shchipunov YA, Schmiedel P. Electrorheological Phenomena in LecithinDecane-Water Mixtures. Journal of colloid and interface science. 1996;179(1):201-6.

41. Shumilina E, Khromova YL, Shchipunov YA. A Study of the Structure of Lecithin Organic Gels by Fourier Transform IR Spectroscopy.

42. Shchipunov YA. Lecithin organogel: a micellar system with unique properties. Colloids and Surfaces A: Physicochemical and Engineering Aspects. 2001;183:541-54.

43. Shchipunov YA, Shumilina EV, Hoffmann H. Lecithin organogels with alkylglucosides. Journal of colloid and interface science. 1998;199(2):218-21.

44. Shchipunov YA, Hoffmann H. Thinning and thickening effects induced by shearing in lecithin solutions of polymer-like micelles. Rheologica acta. 2000;39(6):542-53.

45. Voit A, Shchipunov YA. Dynamics of polymer-like lecithin micelles. Rheological measurements. Colloid journal. 2000;62(4):424-30.

46. Shchipunov YA, Mezzasalma S, Koper G, Hoffmann H. Lecithin organogel with new rheological and scaling behavior. The Journal of Physical Chemistry B. 2001;105(43):104848. 
47. Calpena Campmany AC, Clares Naveros B, Fernández F. Technological, biopharmaceutical and pharmacokinetic advances: new formulations of application on the skin and oral mucosa. Recent Advances in Pharmaceutical Sciences, 2011, Chapter 8, p 175-198 Editor: Diego Muñoz-Torrero. 2011.

48. Renukuntla J, Vadlapudi AD, Patel A, Boddu $\mathrm{SH}$, Mitra AK. Approaches for enhancing oral bioavailability of peptides and proteins. International journal of pharmaceutics. 2013 Apr 15;447(1-2):75-93.

49. Ruiz MA, Clares B, Morales ME, Gallardo V. Preparation, rheological study, and characterization of an organogel as a system for transdermal release of active principles. Pharm Dev Technol. [Research Support, NonU.S. Gov't]. 2007;12(6):637-44.

50. Boddu SH, Alsaab H, Umar S, Bonam SP, Gupta H, Ahmed S. Anti-inflammatory effects of a novel ricinoleic acid poloxamer gel system for transdermal delivery. International journal of pharmaceutics. 2014.

51. Pandey M, Belgamwar V, Gattani S, Surana S, Tekade A. Pluronic lecithin organogel as a topical drug delivery system. Drug Deliv. 2010 Jan;17(1):38-47.

52. Djekic L, Primorac M. Percutaneous Penetration Enhancement Potential of Microemulsion-Based Organogels. Percutaneous Penetration Enhancers Chemical Methods in Penetration Enhancement: Springer; 2016. p. 263-82.

53. Sahoo S, Kumar N, Bhattacharya C, Sagiri S, Jain K, Pal K, et al. Organogels: Properties and Applications in drug delivery. Designed Monomers and Polymers. 2011;14(2):95-108.

54. Almeida H, Amaral MH, Lobão P, Lobo JMS. Pluronic ${ }^{\circledR} \quad$ F-127 and Pluronic Lecithin Organogel (PLO): Main features and their applications in topical and transdermal administration of drugs. Journal of Pharmacy \& Pharmaceutical Sciences. 2012;15(4):592605.

55. Dumortier G, Grossiord JL, Agnely F, Chaumeil JC. A review of poloxamer 407 pharmaceutical and pharmacological characteristics. Pharmaceutical research. 2006;23(12):2709-28.

56. Dumortier G, Grossiord, J. L.,Agnely, F.,Chaumeil, J. C. A review of poloxamer 407 pharmaceutical and pharmacological characteristics. Pharmaceutical research. [Review]. 2006 Dec;23(12):2709-28.

57. Zhang L, Parsons, D. L., Navarre, C. and Kompella, U. B. Development and in-vitro evaluation of sustained release poloxamer 407
(P407) gel formulations of ceftiofur. Journal of controlled release : official journal of the Controlled Release Society. [Research Support, Non-U.S. Gov't]. 2002 Dec 13;85(13):73-81.

58. Gandra SCR. The Preparation and Characterization of Poloxamer-based Temperature-sensitive Hydrogels for Topical Drug Delivery: University of Toledo; 2013.

59. Shrewsbury RP. Applied pharmaceutics in contemporary compounding. Morton Publishing Company; 2015.

60. Boddu S, Bonam SP, Wei Y, Alexander K. Preparation and in vitro evaluation of a pluronic lecithin organogel containing ricinoleic acid for transdermal delivery. International journal of pharmaceutical compounding. 2013;18(3):256-61.

61. Bonam SP. Preparation and Evaluation of Pluronic Lecithin Organogel Containing Ricinoleic acid for Transdermal Drug Delivery: University of Toledo; 2013.

62. Boothe DM. Transdermal gel delivery in cats: fuss or must?(Proceedings). 2011.

63. Murdan S. A review of pluronic lecithin organogel as a topical and transdermal drug delivery system. Hospital pharmacist. 2005;12(7):267-70.

64. Bleicher J, Bhaskara A, Huyck T, Constantino S, Bardia A, Loprinzi CL, et al. Lorazepam, diphenhydramine, and haloperidol transdermal gel for rescue from chemotherapy-induced nausea/vomiting: results of two pilot trials. J Support Oncol. 2008;6(1):27-32.

65. Paice JA, Von Roenn JH, Hudgins JC, Luong L, Krejcie TC, Avram MJ. Morphine Bioavailability from a Topical Gel Formulation in Volunteers. Journal of Pain and Symptom Management. 2008 3//;35(3):31420.

66. Jennifer Hirsh M. Chlorpromazine bioavailability from a topical gel formulation in volunteers. J Support Oncol. 2013;11:144-8.

67. Hoffman S, Yoder A, Trepanier L. Bioavailability of transdermal methimazole in a pluronic lecithin organogel (PLO) in healthy cats. Journal of veterinary pharmacology and therapeutics. 2002;25(3):189-93.

68. Giordano J, Daleo C, Sacks SM. Topical ondansetron attenuates nociceptive and inflammatory effects of intradermal capsaicin in humans. European journal of pharmacology. 1998;354(1):R13-R4.

69. Burnham R, Gregg R, Healy P, Steadward R. The effectiveness of topical diclofenac for lateral epicondylitis. Clinical journal of sport medicine. 1998;8(2):78-81. 
70. Peacock GF, Sauvageot J. Evaluation of the stability of acetaminophen in pluronic lecithin organogel and the determination of an appropriate beyond-use date. International journal of pharmaceutical compounding. 2011;16(5):428-30.

71. Sartor LL, Trepanier LA, Kroll MM, Rodan I, Challoner L. Efficacy and safety of transdermal methimazole in the treatment of cats with hyperthyroidism. Journal of veterinary internal medicine. 2004;18(5):6515.

72. Richards H, Thomas CP, Bowen JL, Heard CM. In-vitro transcutaneous delivery of ketoprofen and polyunsaturated fatty acids from a pluronic lecithin organogel vehicle containing fish oil. Journal of pharmacy and pharmacology. 2006;58(7):903-8.

73. Connor CG, Haine C. Treatment for dry eye using testosterone and progestagen. Google Patents; 2008.

74. Brierre B. Pharmaceutical composition and method for the transdermal delivery of magnesium. Google Patents; 2005.

75. Oronsky BT, Oronsky NC, Oronsky AL. Topical Composition for Treating Pain. Google Patents; 2008.

76. Lee M. Arthro gel and syner gel. Google Patents; 2006.

77. Cusic R, Irsfeld S. Topical analgesic and/or antiinflammatory cream; bursitis, tendonitis; dimethyl sulfoxide and a mixture of pluronic gel and lecithin; allows the longer acting pain relievers ketoprofen and diphenhydramine to reach underlying inflamed tissues. Google Patents; 2005.

78. Scarbrough CA, Scarbrough SS, Shubrook J. Transdermal delivery of metformin. Google Patents; 2012.

79. Wang JJ, Sung K, Huang JF, Yeh CH, Fang JY. Ester prodrugs of morphine improve transdermal drug delivery: a mechanistic study. Journal of pharmacy and pharmacology. 2007;59(7):917-25.

80. Hadgraft J, Pugh WJ, Wolff Hm. Transdermal delivery of some anti-emetics. International journal of pharmaceutics. 1995 9/12/;123(2):285-9.

81. Glisson JK, Wood RL, Kyle PB, Cleary JD. Bioavailability of Promethazine in a Topical Pluronic Lecithin Organogel: A Pilot Study. International journal of pharmaceutical compounding. 2004;9(3):242-6.

82. Igorzata Krajnik M, Zylicz Z, Finlay I, Luczak J, van Sorge AA. Potential uses of topical opioids in palliative care-report of 6 cases. Pain. 1999;80(1):121-5.
83. Krajnik M, Zylicz Z. Topical morphine for cutaneous cancer pain. Palliative medicine. 1997;11(4):325.

84. Wilken M, Ineck JR, Rule AM. Chronic arthritis pain management with topical morphine: case series. Journal of Pain and Palliative Care Pharmacotherapy. 2005;19(4):39-44.

85. Lugo RA, Kern SE. Clinical pharmacokinetics of morphine. Journal of Pain and Palliative Care Pharmacotherapy. 2002;16(4):5-18.

86. Roy SD, Flynn GL. Transdermal delivery of narcotic analgesics: comparative permeabilities of narcotic analgesics through human cadaver skin. Pharmaceutical research. 1989;6(10):825-32.

87. Krotscheck U, Boothe DM, Boothe $H$. Evaluation of transdermal morphine and fentanyl pluronic lecithin organogel administration in dogs. Veterinary therapeutics: research in applied veterinary medicine. 2003;5(3):202-11.

88. Ribeiro MD, Joel SP, Zeppetella G. The bioavailability of morphine applied topically to cutaneous ulcers. Journal of pain and symptom management. 2004;27(5):434-9.

89. Zeppetella G, Paul J, Ribeiro MD. Analgesic efficacy of morphine applied topically to painful ulcers. Journal of pain and symptom management. 2003;25(6):555-8.

90. Ghosh TK, Bagherian A. Development of a transdermal patch of methadone: in vitro evaluation across hairless mouse and human cadaver skin. Pharmaceutical development and technology. 1996;1(3):285-91.

91. Sylvester RK, Schauer C, Thomas J, Steen P, Weisenberger A. Evaluation of methadone absorption after topical administration to hospice patients. Journal of pain and symptom management. 2011;41(5):828-35.

92. Smith TJ, Ritter JK, Poklis JL, Fletcher D, Coyne PJ, Dodson P, et al. ABH gel is not absorbed from the skin of normal volunteers. Journal of pain and symptom management. 2012;43(5):961-6.

93. Fletcher DS, Coyne PJ, Dodson PW, Parker GG, Wan W, Smith TJ. A Randomized Trial of the Effectiveness of Topical "ABH Gel'(Ativan $\AA$, Benadryl ${ }^{\circledR}, \quad$ Haldol $\AA$ ) vs. Placebo in Cancer Patients With Nausea. Journal of pain and symptom management. 2014;48(5):797-803.

94. Prohotsky DL, Juba KM, Zhao F. Formulation and Stability of an Extemporaneously Compounded Oral Solution of Chlorpromazine $\mathrm{HCl}$. Journal of pain \& palliative care pharmacotherapy.28(4):367-70. 
95. Alvarez-Figueroa MJ, González-Aramundiz JV. Passive and iontophoretic transdermal penetration of chlorpromazine. Pharmaceutical development and technology. 2008;13(4):2715 .

96. Alsaab H, Alzhrani RM, Boddu SH. Evaluation of the percutaneous absorption of chlorpromazine from PLO gels across porcine ear and human abdominal skin. Drug development and industrial pharmacy. 2015:19.

97. Bertrand H, Kyriazis M. Topical formulation for pain relief. Google Patents; 2014.

98. Goto S, Kawata M, Suzuki T, Kim NS, Ito C. Preparation and evaluation of eudragit gels. I: Eudragit organogels containing drugs as rectal sustained-release preparations. Journal of pharmaceutical sciences. 1991;80(10):958-61.

99. Adams DJ. Dipeptide and Tripeptide Conjugates as Low-Molecular-Weight Hydrogelators. Macromolecular Bioscience. 2011;11(2):160-73.

100. Toro-Vazquez J, Morales-Rueda J, DibildoxAlvarado E, Charo-Alonso M, Alonzo-Macias M, González-Chávez M. Thermal and textural properties of organogels developed by candelilla wax in safflower oil. Journal of the American Oil Chemists' Society. 2007;84(11):989-1000.

101. Chandrashekar N, Rani RS. Physicochemical and pharmacokinetic parameters in drug selection and loading for transdermal drug delivery. Indian journal of pharmaceutical sciences. 2008;70(1):94.

102. Hoffmann G, Marks S, Taboada J, Hosgood G, Wolfsheimer K. Transdermal methimazole treatment in cats with hyperthyroidism. Journal of Feline medicine and surgery. 2003;5(2):77-82.

103. Ciribassi J, Luescher A, Pasloske KS, Robertson-Plouch C, Zimmerman A, Kaloostian-Whittymore L. Comparative bioavailability of fluoxetine after transdermal and oral administration to healthy cats. American journal of veterinary research. 2003;64(8):994-8.

104. Dowling TC, Arjomand M, Lin ET, Allen LV, McPherson ML. Relative bioavailability of ketoprofen $20 \%$ in a poloxamer-lecithin organogel. American journal of health-system pharmacy. 2004;61(23):2541-4.

105. Lehman PA, Raney SG. In vitro percutaneous absorption of ketoprofen and testosterone: comparison of pluronic lecithin organogel vs. pentravan cream. International journal of pharmaceutical compounding. 2012;16(3):248-52.

106. Grace D, Rogers J, Skeith K, Anderson K. Topical diclofenac versus placebo: a double blind, randomized clinical trial in patients with osteoarthritis of the knee. The Journal of rheumatology. 1999;26(12):2659-63.

107. Mealey K, Peck K, Bennett B, Sellon R, Swinney G, Melzer K, et al. Systemic absorption of amitriptyline and buspirone after oral and transdermal administration to healthy cats. Journal of veterinary internal medicine. 2004;18(1):43-6.

108. Pandey M, Belgamwar V, Gattani S, Surana S, Tekade A. Pluronic lecithin organogel as a topical drug delivery system. Drug delivery. 2010;17(1):38-47.

109. Kryger AH. Topical testosterone formulations and associated methods. Google Patents; 2004.

110. Jones $\mathrm{M}$. The history of pluronic lecithin organogel. Int J Pharm Compd. 2003;7:180-3.

111. Boddu SHS, Gupta H, Bonam SP. Preclinical evaluation of a ricinoleic acid poloxamer gel system for transdermal eyelid delivery. International journal of pharmaceutics. 2014 8/15/;470(1-2):158-61.

112. Boddu SHS, Alsaab H, Umar S, Bonam SP, Gupta H, Ahmed S. Anti-inflammatory effects of a novel ricinoleic acid poloxamer gel system for transdermal delivery. International journal of pharmaceutics. 2015 2/1/;479(1):207-11.

113. Parhi R, Suresh P, Pattnaik S. Pluronic lecithin organogel (PLO) of diltiazem hydrochloride: effect of solvents/penetration enhancers on ex vivo permeation. Drug delivery and translational research. 2016:1-11.

114. Dumortier G, Grossiord, Jean., Agnely, Florence., and Chaumeil, Jean. A Review of Poloxamer 407 Pharmaceutical and Pharmacological Characteristics. Pharm Res. 2006;23(12):2709-28. 